\title{
Assessment of the predatory capacity on mosquito larvae of Jenynsia multidentata (Anablepidae) in presence of vegetation under laboratory conditions
}

\author{
Maria I. Garcia'1,2 (D) Albérico F. Murúa'1,2 (1), Leonardo M. Díaz-Nieto1,2 (D), Juan C. Acosta ${ }^{1,3}$ (D), \\ Claudia de Los Rios' (i), Florencia A. Cano² (1) \& Graciela M. Blanco ${ }^{1,3}$ (i)
}

\begin{abstract}
1. Dpto. de Biología, Facultad de Ciencias Exactas Físicas y Naturales, Universidad Nacional de San Juan. CONICET (Consejo Nacional de Investigaciones Científicas y Técnicas), Argentina. Av. Ignacio de la Roza, 590 Oeste, Complejo Universitario "Islas Malvinas" (CPA 5402), Rivadavia, San Juan, Argentina. (merygarcia24@gmail.com) 2. Instituto y Museo de Ciencias Naturales, Universidad Nacional de San Juan, Facultad de Ciencias Exactas Físicas y Naturales, Av. España, 400 N (CPA 5400) San Juan, Argentina

3. CIGEOBIO-CONICET. Facultad de Ciencias Exactas, Físicas y Naturales, Universidad Nacional de San Juan. Av. Ignacio de la Roza, 590 Oeste, Rivadavia, San Juan, CPA: J5402DCS
\end{abstract}

Received 6 March 2018

Accepted 9 February 2019

Published 28 March 2019

DOI 10.1590/1678-4766e2019011

\begin{abstract}
Larvivorous fish have been studied as potential biocontrol agents of mosquito larvae and pupae through their trophic interactions. The use of native fish for mosquito control may have benefits for both aquatic biodiversity and human health. Evaluating the effect of vegetation on the predatory efficacy is fundamental to determine if this species can be used as a biocontrol agent. With the aim of evaluating Jenynsia multidentata (Jenyns, 1842) as a biocontrol agent of Culex pipiens Linnaeus, 1758, we tested its predatory capacity in the presence or absence of aquatic vegetation under laboratory conditions. Two independent experiments were conducted. Larval consumption at a density of 60 larvae (6 larvae/1) was significantly reduced with the vegetation increased. On the other hand, when the larval density was 120 (12 larvae/1), the predatory capacity of $J$. multidentata did not vary in the presence or absence of vegetation. This result indicated that vegetation effect on consumption could be related to prey density, since at the higher density of prey the probability of predator-prey encounter might be increased. Jenynsia multidentata is a good consumer in presence of vegetation and could be used as a potential biocontrol agent of mosquito larvae in natural environments with similar characteristics to the ones tested in these experiments.
\end{abstract}

KEYWORDS. Biocontrol agents, Culex larvae, larvae density, consumption rate.

RESUMEN. Evaluación de la capacidad depredadora de Jenynsia multidentata (Anablepidae) sobre larvas de mosquitos en presencia de vegetación en condiciones de laboratorio. Los peces larvívoros han sido estudiados como posibles agentes de control biológico de larvas y pupas de mosquitos a través de sus interacciones tróficas. El uso de peces nativos para el control de mosquitos puede tener beneficios tanto para la biodiversidad acuática como para la salud humana. La evaluación del efecto de la vegetación sobre la eficacia depredadora es fundamental para determinar si esta especie puede usarse como un agente de control biológico. Con el objetivo de evaluar a Jenynsia multidentata (Jenyns, 1842) como agente de biocontrol de Culex pipiens Linnaeus, 1758, probamos su capacidad depredadora en presencia o ausencia de vegetación acuática en condiciones de laboratorio. Se llevaron a cabo dos experimentos independientes. El consumo de larvas a una densidad de 60 larvas (6 larvas / 1) se redujo significativamente con el aumento de la vegetación. Por otro lado, cuando la densidad larval fue de 120 (12 larvas / 1), la capacidad depredadora de $J$. multidentata no varía en la presencia o ausencia de vegetación. Este resultado indicó que el efecto de la vegetación en el consumo podría estar relacionado con la densidad de presas, ya que a mayor densidad de presas se podría incrementar la probabilidad de encuentro entre depredador y presa. Jenynsia multidentata es un buen consumidor en presencia de vegetación y podría ser usado como un potencial agente de control biológico de larvas de mosquitos en ambientes naturales con características similares a las probadas en estos experimentos.

PALABRAS CLAVE. Agentes de biocontrol, larva de Culex, densidad larval, tasa de consumo.

The control of Culicidae based on chemical strategies causes a major impact on the environment and insecticides resistance in target species despite their efficiency (RAULINS $\&$ WAN, 1995). Since the 1980 s, the anti-vectorial fight includes predation, parasitism and competition in a context of integrated mosquito management (WHO, 2004; KARUNAMOORTHI, 2011). Exotic fish species have been introduced to many areas worldwide because of their alleged ability to control mosquito larvae, but have become one of the main threats to biodiversity (GARCÍA-BERTHOU, 2007;
PYKE, 2008). Larvivorous fishes such as Gambusia affinis (Baird \& Girard, 1853) and Gambusia holbrooki Girard, 1859 , both native to freshwater basins of the east coast of the USA, were introduced in different countries for the biological control of mosquitoes (MENON \& RAJAGOPALAN, 1978; Bence \& Murdoch, 1986; ChatterJee \& Chandra, 1997; CABRAL et al., 1998). At present, their negative impact on native species is being evaluated (HURLBERT et al., 1972; CARMONA-CATOT et al., 2013; WHO, 2016); nevertheless, governments continue to spend considerable funds on the 
introduction of exotic fish species without knowledge of their biology, possible ecological risk and efficacy in biological control (El-SabaAWi et al., 2016; SERVICK, 2016). Recently, CABRERA et al. (2017) confirmed the presence of two species of the non-native mosquitofish G. affinis and G. holbrooki in Argentina, 70 years after its introduction, and highlighted that some health officials had recently released fishes to fight the transmission of dengue fever. This would suggest an indiscriminate introduction of these fish in this region.

Either way, some studies suggest that native fish can be equally or even more effective than exotic species as biocontrol agents (NeLSON \& LeWIs, 1992; HoMSKI et al., 1994). Jenynsia multidentata (Jennyns, 1842) could be a biocontrol agent of mosquito species from Argentina. This fish is distributed in South America, in the River Plate, from Río de Janeiro in Brazil to central Argentina and Uruguay (GhedotTi \& Weitzman, 1996). It is an omnivorous species (RINGUELET, 1967), strongly euryhaline (BAIGúN et al., 2002) and associated with aquatic vegetation (EsCALANTE, 1983; MenNi, 2004; QueZada-Romegialli et al., 2009). The predation capacity of $J$. multidentata was evaluated under laboratory and field conditions with different results (MARTI et al., 2006, BONIFACIO et al., 2014), vegetation effect on predation efficiency is an important factor to consider if larvivorous fish are used as biocontrol agents in the environment, and such study has not been carried out in $J$. multidentata until now.

In coastal areas, the aquatic vegetation is an important biological component due to the diverse and abundant communities it supports, often much larger than unvegetated areas (CROWDER et al., 1998). The diversity and abundance of macroinvertebrates generally increase with expanding vegetation biomass or density (CROWDER \& COOPER, 1982; STONER \& LEWIS, 1985). It is well known that some kinds of emergent vegetation favor mosquito's reproduction (JIANNINO $\&$ Walton, 2004). For instance, Culex pipiens Linnaeus 1758 , vector mosquito of St. Louis encephalitis virus (SLEV), West Nile virus (WNV), Rift Valley Fever virus (RVFV), filarial worms and some other wildlife pathogens like bird malaria (FARAJOLLAHI et al., 2011), uses marsh habitats as natural breeding where Typha dominguensis Persson spreads along the perimeter (MUfARREGE et al., 2011). In emergent vegetation, Culicidae larvae and pupae obtain food and protection from predators (ALMIRÓN \& BREWER, 1996; THULLEN et al., 2002).

The aquatic vegetation is used by macroinvertebrates as shelter (DIEHL, 1988), reducing predator-prey interactions (Werner et al., 1983; SiH, 1986; Sharma, 1987; SaVIno \& Stein, 1989; Rojas et al., 2004; Willems et al., 2005). ABDEL-TAWWAB (2005) suggested that fish foraging success generally decreases as plant density increases, but this has not been determined with $J$. multidentata. There are several characteristics that a larvivorous fish must possess to be an efficient biocontroller and one of them is to be able to predate through vegetation (AHMED et al., 1986). The aim of this study was to determine the predatory capacity of $J$. multidentata on C. pipiens larvae in relation with the presence or absence of aquatic vegetation under laboratory conditions.

\section{MATERIAL AND METHODS}

Jenynsia multidentata (total length 5-7 cm) were captured with hand nets ( $1 \mathrm{~mm}$ mesh size) from the artificial lagoons of the Institute of Hydrobiological Development (31 $\left.31^{\prime} 50.37^{\prime \prime} \mathrm{S}, 68^{\circ} 32^{\prime} 15.15^{\prime \prime} \mathrm{W}\right)$, San Juan province, Argentina. The specimens of $J$. multidentata (10우, 20.IV.2014) used in the experiment became part of the Scientific Collection of Vertebrates of the Institute and Museum of Natural Sciences of the National University of San Juan, Argentina. Mosquito larvae were collected with a $300 \mathrm{ml}$ dipper from urban irrigation ditches, transported to the laboratory in a $250 \mathrm{ml}$ plastic container and reared to fourth-instar. Culex pipiens larvae identification was based on taxonomic key from Mitchell \& Darsie (1985) and Rossi et al. (2002).

Laboratory experiment. Habitats with different stem densities were simulated in an indoor laboratory to investigate the influence of emergent vegetation on the predatory capacity of $J$. multidentata. Laboratory experiments were conducted in 201 containers with $1 \mathrm{~kg}$ of sand as substrate, 101 of dechlorinated water and one $J$. multidentata female. The area of the container and water depth were $616 \mathrm{~cm}^{2}$ and $20 \mathrm{~cm}$ respectively. The emergent vegetation of mosquito breeding habitats was simulated with dry Arundo donax Linnaeus, 1753 stems of $2 \mathrm{~cm} \pm 0.23$ in diameter and $30 \mathrm{~cm}$ in length. The experimental containers were kept at room temperature and water temperature was recorded by means of a data logger. The water temperature was $17.84 \pm 1^{\circ} \mathrm{C}$.

The first experiment was conducted in 30 containers, 10 of which included 20 dry stems at $5 \mathrm{~cm}$ (20 stems / 616 $\mathrm{cm}^{2}$ ) that were distributed across the surface of the container (T1), 10 containers had 10 stems at $5 \mathrm{~cm}\left(10\right.$ stems $\left./ 308 \mathrm{~cm}^{2}\right)$ in half of the container (T2) and the remaining 10 were left free of vegetation as control treatment (TC). After a 24-hour fast to standardize hunger levels, J. multidentata females were fed daily with 60 fourth-instar C. pipiens larvae for 7 days. The surviving larvae were counted and removed after $24 \mathrm{~h}$. The second experiment was like the first one only that in this case $\mathrm{T} 2$ was eliminated and J. multidentata females were fed daily with 120 fourth-instar $C$. pipiens larvae. To maintain adequate oxygenation levels in the experimental containers in both experiments, a partial water refill corresponding to $25 \%$ of the total volume was carried out daily.

Data analysis. Normality and homogeneity of variance were analyzed using the Levene test and Shapiro Wilk tests respectively. To compare the consumption between treatments, Kruskal-Wallis tests and Tukey test $(\mathrm{p}=0.05)$ were carried out in experiment 1 and Mann-Whitney U test (Sokal \& RoHLf, 1969) in experiment 2. Finally, the Spearman correlation coefficient was used to analyze the 
relationship between consumption and days. The R Studio Version 1.0.136 was employed for statistical analyses.

\section{RESULTS}

The average number of $C$. pipiens larvae consumed by $J$. multidentata at a larval density of 6 larvae/ $(n=60)$ (Fig. 1) was $50 \pm 15.8 / 24 \mathrm{~h}$ in T1 and $60 / 24 \mathrm{~h}$ in T2 and TC, with significant differences observed $(\mathrm{H}=70, \mathrm{p}=5.062 \mathrm{e}-16)$. In T1, J. multidentata consumption was significantly reduced compared to $\mathrm{T} 2$ and $\mathrm{TC}$, and it was an equally effective consumer in the treatment with area free of vegetation (T2) and TC (Fig. 1). Days were not a statistically significant variable $(\mathrm{r}=-0.05$, $\mathrm{p}$-value $=0.5)$ in this experiment (Fig. 2).

The average number of $C$. pipiens larvae consumed by $J$. multidentata at a density of 12 larvae/1 $(\mathrm{n}=120)$ larvae was $84 \pm 27.5$ in T1 and $78 \pm 28$ in TC. J. multidentata was equally effective as a mosquito larvae consumer in the treatment with stems (T1) and TC (W=1404, $\mathrm{p}=0.28)$ (Fig. 3). In this experiment, there was a significant effect of days on larval consumption with a negative correlation $(\mathrm{r}=-0.55$, p-value=2e-09) (Fig. 4).

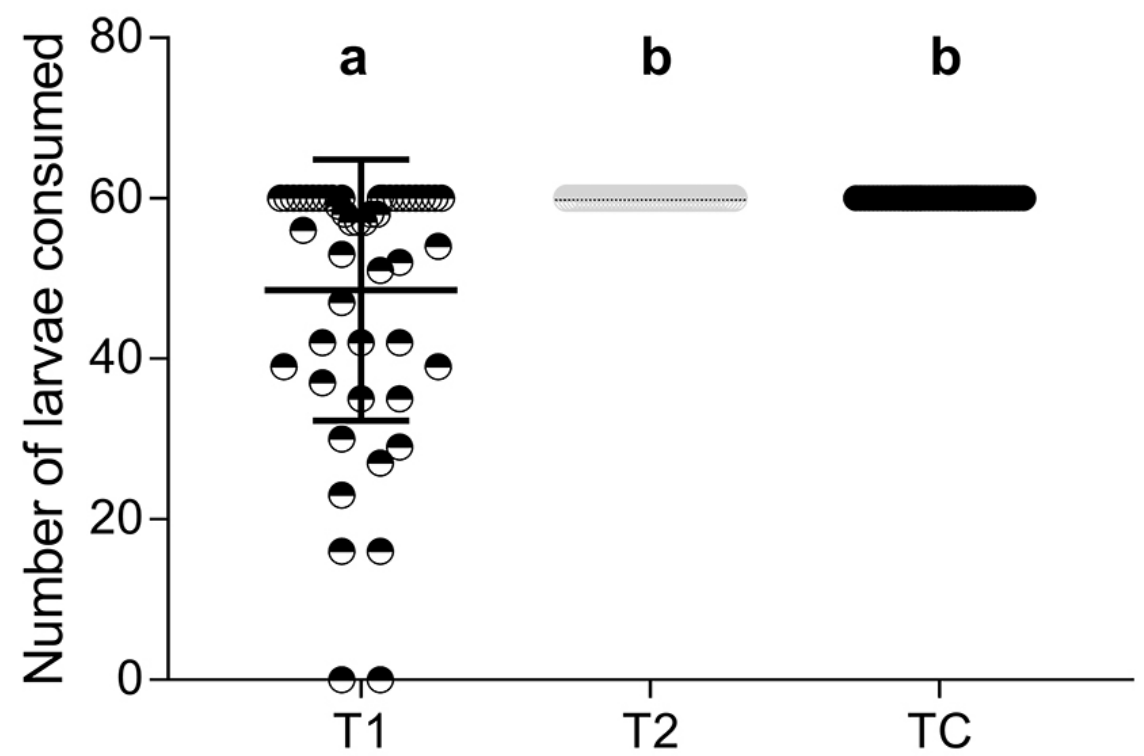

Fig. 1. Jenynsia multidentata (Jenyns, 1842) consumption of 60 Culex pipiens Linnaeus, 1758 fourth-stage larvae at different vegetation densities: (T1) 20 stems, (T2) 10 stems and (TC) without stems. Each circle represents the daily consumption of a female specimen and the horizontal bars indicate the average consumption. The letters $(a, b)$ at the top of the figure indicate significant differences between treatments $(\mathrm{p}<0.05)$.

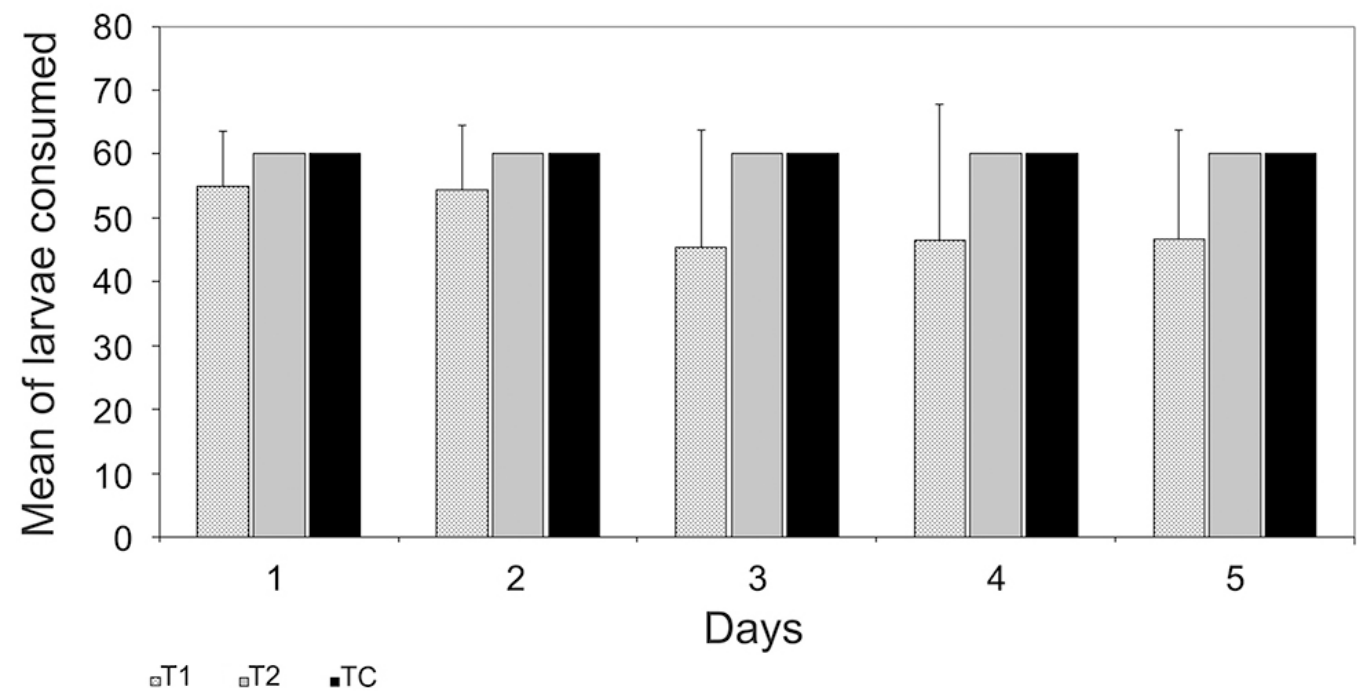

Fig. 2. Daily consumption (mean \pm SD) of Jenynsia multidentata (Jenyns, 1842) on 60 Culex pipiens Linnaeus, 1758 fourth-stage larvae at different densities of vegetation: (T1) 20 stems, (T2) 10 stems and (TC) without stems, for 5 days. 


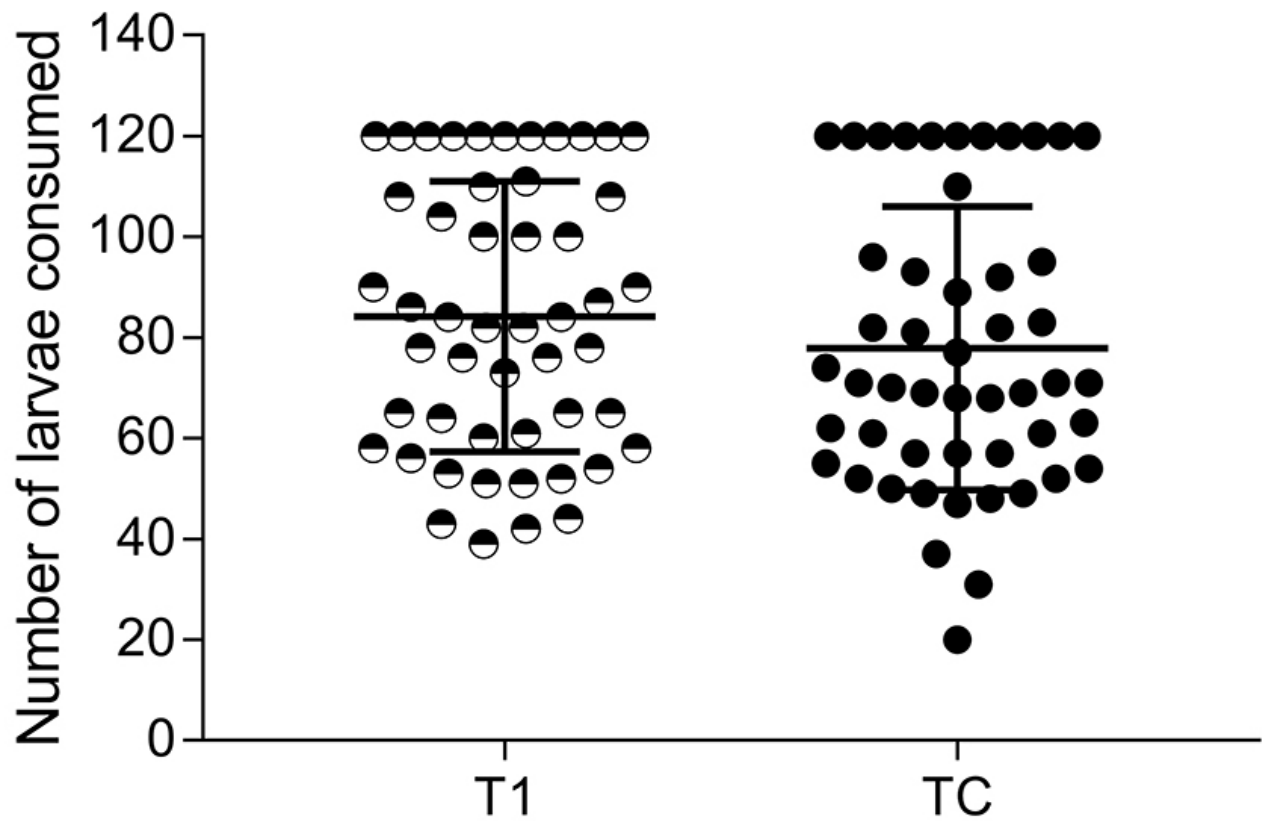

Fig. 3. Jenynsia multidentata (Jenyns, 1842) consumption of 120 Culex pipiens Linnaeus, 1758 fourth-stage larvae at different vegetation densities: (T1) 20 stems and (TC) without stems. Each circle represents the daily consumption of a female specimen and the horizontal bars indicate the average consumption.

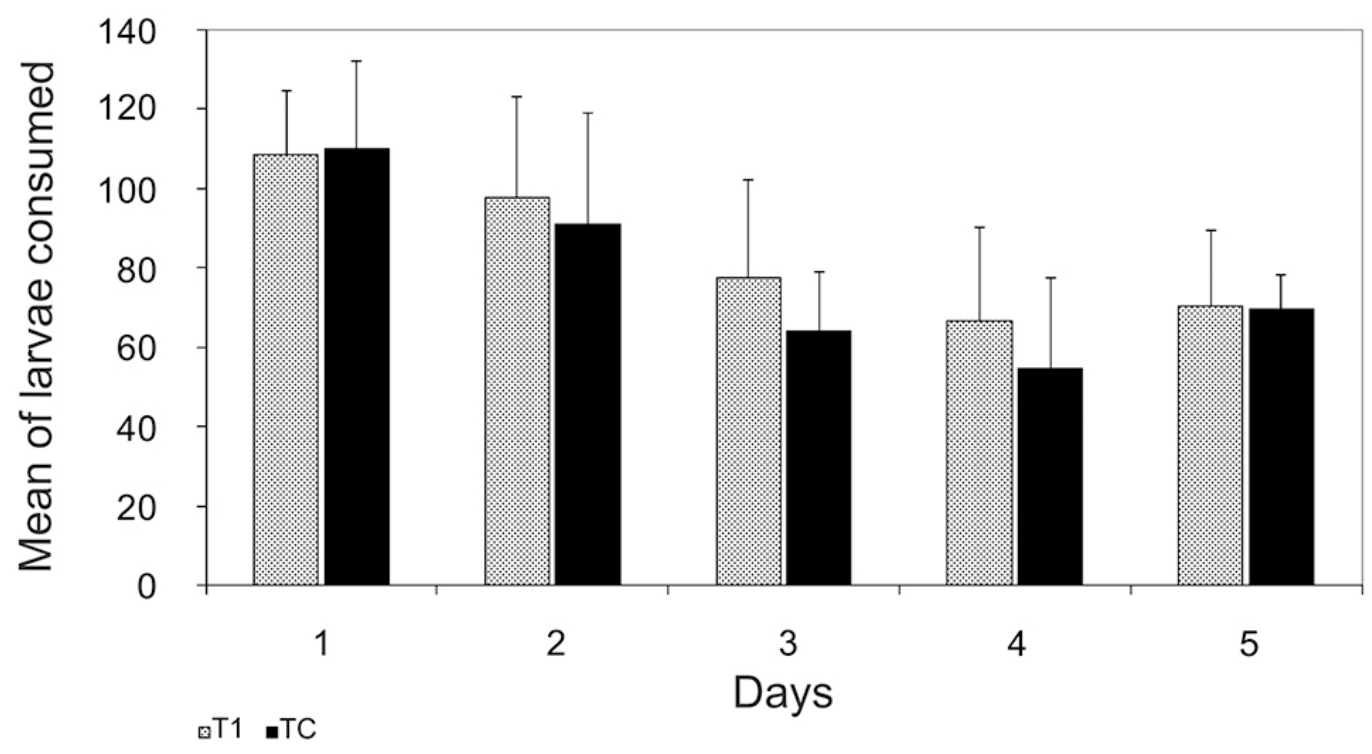

Fig. 4. Daily consumption (mean $\pm \mathrm{SD}$ ) of Jenynsia multidentata (Jenyns, 1842) on 120 Culex pipiens Linnaeus, 1758 fourth-stage larvae. (T1) 20 stems, (TC) without stems, for 5 days

\section{DISCUSSION}

The use of larvivorous fish as a method of biological control of mosquito larvae is dated; there are relatively few studies that evaluate the vegetation effect on mosquito larvae predation efficiency and none of $J$. multidentata. This parameter is fundamental to determine if a larvivorous fish species can be used as biocontrol agent in marsh areas where macrophytes are predominant. Emerging vegetation obstructs the visual field and hinders the swimming behavior of forage fish (DieHL, 1988; ManUtange et al., 2000). Studies that were carried out with other fish species obtained different results; for instance, WiLLEMS et al. (2005) concluded that vegetation density has a negative correlation with larval consumption in Pseudomugil signifier Kner, 1866 and G. holbrooki, while CABRAL et al. (1998) determined that vegetation has no effect on prey consumption in field experiment with G. holbrooki.

Our results showed that $J$. multidentata is a good consumer through vegetation. However, we observed differences in the two experiments carried out with dissimilar number of larvae. Experiment 1 (60 mosquito larvae) showed that $J$. multidentata predatory capacity on $C$. pipiens larvae 
was maximum in both treatments, with vegetation plus free area and control. Probably, the low larval density coupled with vegetation decreased the predator-prey encounter.

On the other hand, in experiment 2 (120 mosquito larvae), the predatory capacity of $J$. multidentata was not reduced in the presence of vegetation and the average consumption rate was higher than in experiment 1 in $\mathrm{T} 1$ and TC. This could be due to the increase in the number of larvae that were exposed, which could increase both the probability of predator-prey encounter and prey contrast with vegetation (CABRAL et al., 1998), or because the time spent searching and identifying a prey depends on larval concentration (Holling \& BUCKINGHAM, 1976). Larval consumption was considerably reduced over days, probably because of the rise in larval density that increased the survival rate of the prey in experiment 2 . The reason for this could be the prey handling time that limits the number of prey the predator can process per unit of time (HoLling \& BUCKINGHAM, 1976).

The consumption rate of $J$. multidentata under the tested conditions was like the one found in other larvivorous fish that were evaluated and proposed as biocontrol agents, such as Girardinus metallicus Poey, 1854 (Hernández Contreras et al., 2004), P. signifer, G. holbrooki (WILLEMS et al., 2005), Poecilia reticulata Peters, 1859, Carassius auratus auratus (Linnaeus, 1758) (VALERO et al., 2006) and Cnesterodon decemmaculatus (Jenyns, 1842) (MARTI et al., 2006; TRANCHIDA et al., 2010). Jenynsia multidentata consumption results obtained by MARTI et al. (2006) at a density of 60 larvae were like those achieved in this experiment and inferior at a larval density of 120 . The results showed that $J$. multidentata predatory capacity was greater, even in the presence of vegetation, than those obtained by other authors in experiments without vegetation (MARTI et al., 2006, Bonifacio et al., 2014). This could be due to the differences in water volume used in both experiments. Lower predatory capacity was observed in J. multidentata females in experiments with small volumes of water (BONIFACIO et al., 2014). The fish energy expenditure could decrease with a lower volume of water that, in turn, would reduce the consumption of larvae. There is probably a relationship between the consumption capacity of $J$. multidentata and the water volume available for the fish to swim.

The use of indigenous fish for mosquito control may have benefits for both aquatic biodiversity and human health (LAWRENCE et al., 2016). Our results would indicate that since $J$. multidentata is a good consumer of larvae among vegetation, it could be used as a potential biocontrol agent of mosquito larvae in natural environments with similar characteristics to the ones tested in the present study. Further research will be necessary to determine whether the results observed in laboratory conditions are similar in natural breeding sites of mosquitoes.

Acknowledgements. For the identification and culture of the fish, we would like to thank Javier Varas and Irma Terzano (Institute of Hydrobiological Development, San Juan, Argentina). We especially thank Elisa Murúa for the critical revision of the translation.

\section{REFERENCES}

ABDEL-TAwwAB, M. 2005. The effect of artificial vegetation density on growth and growth-related parameters of Nile tilapia, Oreochromis niloticus (L.) fry. Turkish Journal of Fisheries and Aquatic Sciences 5:63-68. Ahmed, S. S.; Linden, A. L. \& CECH, J. J. 1986. A rating system for the selection of indigenous fish species for mosquito control. World Health Organization/VBC/934.

Almirón, W. R. \& Brewer, M. E. 1996. Classification of immature stage habitats of Culicidae (Diptera) collected in Córdoba, Argentina. Memórias do Instituto Oswaldo Cruz 91:1-9.

Baigún, C.; LóPez, G.; Dománico, A.; Ferriz, R.; Sverliu, S. \& Schenke, R. D. 2002. Presencia de Corydoras paleatus (Jenyns, 1842), una nueva especie brasílica en el norte de la Patagonia (río Limay) y consideraciones ecológicas relacionadas con su distribución. Ecología Austral 12:41-48.

Bence, J. \& Murdoch, W. 1986. Prey size by the mosquitofish: Relation to optimal diet theory. Ecology 67:324-336.

Bonifacio, A. F.; Aun, M. L. \& Martori, R. A. 2014. Caracterización del consumo de larvas de culícidos (Diptera) en dos especies de peces indígenas de la zona central de Argentina. Iheringia, Série Zoologia 104:284-289.

Cabral, J. A.; Miero, C. L. \& Marques, J. C. 1998. Environmental and biological factors influence the relationship between a predator fish, Gambusia holbrooki, and its main prey in rice fields of the Lower Mondego River Valley (Portugal). Hydrobiologia 382:41-51.

Cabrera, M. B.; Bogan, S.; Posadas, P.; Somoza, G. M.; MontoyaBurgos, J. I. \& CARdoso, Y. P. 2017. Risks associated with introduction of poeciliids for control of mosquito larvae: first record of the non-native Gambusia holbrooki in Argentina. Journal of Fish Biology 91:704-710.

Carmona-Catot, G.; Magellan, K. \& García-Berthou, E. 2013. Temperature-specific competition between invasive mosquitofish and an endangered cyprinodontid Fish. PLoS ONE 8:e54734.

Chatterjee, S. N. \& Chandra, G. 1997. Laboratory trials on the feeding pattern of Anopheles subpictus, Culex quinquefasciatus and Armigeres subalbatus larvae by Gambusia affinis. Scientific Culture 63:51-52.

Crowder, L. B. \& Cooper, W. E. 1982. Habitat structural complexity and the interaction between bluegills and their prey. Ecology 63:1802-1813.

Crowder, L. B.; McCollum, E. W. \& Martin, T. H. 1998. Changing perspectives on food web interactions in lake littoral zones. In: JEPPESEN, E.; Sondergaard, M. \& Christoffersen, K. eds. The structuring roles of submerged macrophytes in lakes. New York, Springer, p. 240-249.

DiEHL, S. 1988. Foraging efficiency of three freshwater fishes: effects of structural complexity and light. Oikos 53:207-214.

El-Sabahiwi, R. W.; Frauendorf, T. C.; Marques, P. S.; Mackenzie, R. A.; Manna, L. R.; Mazzoni, R.; Phillip, D. A. T.; Warbanski, M. L. \& ZANDONA, E. 2016. Biodiversity and ecosystem risks arising from using guppies to control mosquitoes. Biology Letters 12:20160590.

Escalante, A. H. 1983. Contribución al conocimiento de las relaciones tróficas de peces de agua dulce del área platense. III. Otras especies. Limnobios 2:453-463.

Farajollahi, A.; Fonseca, D. M.; Kramer, L. D. \& Kilpatrick, A. M. 2011. "Bird biting" mosquitoes and human disease: a review of the role of Culex pipiens complex mosquitoes in epidemiology. Infection, Genetics and Evolution 11:1577-1585.

GARCÍA-BERTHOU, E. 2007. The characteristics of invasive fishes: what has been learned so far? Journal of Fish Biology 71:33-55.

Ghedotti, M. J. \& Weitzman, S. H. 1996. A new species of (Cyprinodontiformes: Anablepidae) from Brazil with comments on the composition and taxonomy of the genus. Occasional Papers of the Natural History Museum of the University of Kansas 179:1-25. Hernández Contreras, N.; Díaz Pérez, M.; Mendiola Martínez, J.; Báez Artelles, J. \& García Ávila, I. 2004. Ingestión de larvas de Culex quinquefasciatus (Diptera: Culicidae) por Girardinus metallicus (Cyprinodontiformes: Poecilidae). Revista Cubana de Medicina Tropical 56:152-155.

Holling, C. S. \& Buckingham, S. 1976. A behavioral model of predator prey functional responses. Behavioral Sciences 3:183-195.

Homski, D.; Goren, M. \& Gasith, A. 1994. Comparative evaluation of the larvivorous fish Gambusia affinis and Aphanius dispar as mosquito control agents. Hydrobiologia 284:137-146. 
Hurlbert, S. H.; Zedler, J. B. \& Fairbanks, D. A. 1972. Ecosystem alteration by mosquitofish (Gambusia affinis) predation. Science 175:639-641.

JiANNINO, J. A. \& WALTON, W. E. 2004. Evaluation of vegetation management strategies for controlling mosquitoes in a southern California constructed wetland. Journal of the American Mosquito Control Association 20:18-26.

KARUNAMOORTHI, K. 2011. Vector control: a cornerstone in the malaria elimination campaign. Clinical Microbiology and Infection 17:16081616.

Lawrence, C.; Rutherford, N.; Hamilton, R. \& Meredith, D. 2016. Experimental evidence indicates that native freshwater fish outperform introduced Gambusia in mosquito suppression when water temperature is below $25^{\circ} \mathrm{C}$. Hydrobiologia 766:357-364.

Manutange, J.; Asaeda, T. \& Priyadarshan, T. 2000. The influence of structural complexity on fish-zooplankton interactions: a study using artificial submerged macrophytes. Environmental Biology of Fishes 58:425-438.

Marti, G.; AzPelicueta, M.; Tranchida, M.; Pelizza, S. \& García, J. 2006. Predation efficiency of indigenous larvivorous fish species on Culex pipiens larvae (Diptera: Culicidae) in drainage ditches in Argentina. Journal of Vector Ecology 31:102-106.

MenNi, R. C. 2004. Peces y ambientes en Argentina continental. Monografías del Museo Argentino de Ciencias Naturales 5:1-316.

Menon, P. \& Rajagopalan, P. 1978. Control of mosquito breeding in wells using Gambusia affinis and Aplocheilus blochii in Pondicherry Town. Indian Journal of Medical Research 68:927-33.

MitCheLL, C. J. \& DARSIE, R. F. JR. 1985. Mosquitoes of Argentina part II. Geographic distribution and bibliography (Diptera, Culicidae). Mosquito Systematics 17:279-362.

Mufarrege, M. M.; Di Luca, G. A.; Hadad, H. R. \& Maine, M. A. 2011. Adaptability of Typha domingensis to high $\mathrm{pH}$ and salinity. Ecotoxicology 20:457-465.

Nelson, S. M. \& Lewis, C. K. 1992. Use of an indigenous fish species, Fundulus zebrinus, in a mosquito abatement program: a field comparison with the mosquitofish, Gambusia affinis. Journal of the American Mosquito Control Association 8:301-304.

Pyke, G. H. 2008. Plague minnow or mosquito fish? A review of the biology and impacts of introduced Gambusia species. Annual Review of Ecology, Evolution, and Systematics 39:171-191.

Quezada-Romegialli, C.; Vila, I. \& Veliz, D. 2009. Nueva especie íctica invasora en aguas continentales de Chile Central: Jenynsia multidentata (JENYNS, 1842) (Cyprinodontiformes: Anablepidae). Gayana 73:23-236.

RaUlins, S. \& WAN, J. O. 1995. Resistance in some caribbean population of Aedes aegypti to several insecticides. Journal of the American Mosquito Control Association 11:59-65.

Ringuelet, R.; Aramburu, R. \& ARAmburu, A. 1967. Los peces argentinos de agua dulce. La Plata, Comisión de Investigación Científica. 602 p.
Rojas, J. E.; Gamboa, M.; Villalobos, S. \& Cruzado, F. 2004. Eficacia del control de larvas de vectores de la malaria con peces larvívoros nativos en San Martín, Perú. Revista Peruana de Medicina Experimental y Salud Pública 21:44-50.

Rossi, G. C.; Mariluis, J. C.; Schnack , J. A. \& Spinelli, G. R. 2002. Dípteros vectores (Culicidae y Calliphoridae) de la Provincia de Buenos Aires. COBIOBO No 4, PROBIOTA n ${ }^{\circ} 3,45 p$.

Savino, J. F. \& Stein, R. A. 1989. Behavior of fish predators and their prey: habitat choice between open water and dense vegetation. Environmental Biology of Fishes 24:287-293.

SERVICK, K. 2016. Ecologists raise alarm over releases of mosquito-killing guppies. Science Magazine. Available at $<\mathrm{http}$ ://www.sciencemag.org/ news/2016/10/ecologists-raise-alarm-over-releases-mosquito-killingguppies/>. Accessed on 11 December 2017.

SHARMA, V. P. 1987. Community-based malaria control in India. Parasitology Today 3:222-226.

SiH, A. 1986. Antipredator responses and the perception of danger by mosquito larvae. Ecological Society of America 67:434-441.

SOKAL, R. R. \& ROHLF, F. J. 1969. Biometry. The principles and practices of statistics in biological research. 2ed. San Francisco, W. H. Freeman. 253p.

Stoner, A. W. \& Lewis, F. G. I. 1985. The influence of quantitative and qualitative aspects of habitat complexity in tropical seagrass meadows. Journal of Experimental Marine Biology and Ecology 94:49-40.

THULLEN, J. S.; SARTORIS, J. J. \& WALTON, W. E. 2002. Effects of vegetation management in constructed wetland treatment cells on water quality and mosquito production. Ecological Engineering 18:441-457.

Tranchida, M. C.; Pelizza, S. A.; Bisaro, V.; Beltrán, C.; Garcia, J. J. \& Micieli, M. V. 2010. Use of the neotropical fish Cnesterodon decemmaculatus for long-term control of Culex pipiens L. in Argentina. Biological Control 53:183-187.

Valero, N.; Meleán, E.; Maldonado, M.; Montiel, M.; Larreal, Y \& Espina, L. 2006. Capacidad larvívora del gold fish (Carassius auratus auratus) y del guppy salvaje (Poecilia reticulata) sobre larvas de Aedes aegypti en condiciones de laboratorio. Revista Científica (Maracaibo) 16:414-419.

Werner, E. E.; Gilliam, J. F.; Hall, D. J. \& Mittelbach, G. G. 1983. An experimental test of the effects of predation risk on habitat use in fish. Ecology 64:1540-1548.

Willems, K. J.; WebB, C. E. \& Rusell, R. C. 2005. A comparison of mosquito predation by the fish Pseudomugil signifer (Kner) and Gambusia holbrooki (Girard) in laboratory trials. Journal of Vector Ecology 30:87-90.

WHO - WORLD HEALTH ORGANISATION. 2004. Global strategic framework for integrated vector management. Report $\mathrm{N}^{\circ} \mathrm{WHO} / \mathrm{CDS} / \mathrm{CPE} /$ PVC/2004.10. Geneva, WHO.

WHO - World HeALth Organisation. 2016. Biological control. Available at $<$ http://www.who.int/denguecontrol/control_strategies/biological control/en/>. Accessed on 11 December 2017. 